\title{
PROGRAM BIMBINGAN DAN KONSELING BERBASIS NILAI-NILAI BUDAYA UNTUK MENINGKATKAN KEMAMPUAN PENYESUAIAN DIRI PESERTA DIDIK
}

\author{
Heru Nurrohman \\ Pengajar Universitas Muhammadyah Palangkaraya \\ heru_nurrohman@gmail.com
}

\begin{abstract}
ABSTRAK
Program bimbingan dan konseling berbasis nilai-nilai budaya dalam penelitian ini didasari pemikiran bahwa, perubahan sosial-budaya yang begitu cepat dan masif membuat peserta didik mengalami kesulitan untuk menyesuaikan diri. Ketidakmampuan menyesuaikan diri baik terhadap tuntutan lingkungan sosial budaya (keluarga, sekolah, dan masyarakat) maupun terhadap kebutuhan pribadi, menyebabkan peserta didik berperilaku amoral yang bertentangan dengan norma (nilai), sehingga peserta didik membutuhkan bantuan bimbingan dan konseling untuk menginternalisasikan nilai-nilai budaya sebagai pedoman dalam menyesuaikan diri. Layanan bimbingan dan konseling yang berakar pada budaya Indonesia, memerlukan sebuah konsep teoretik dan empirik yang mampu mengintegrasikan nilai-nilai budaya pada seluruh bahan dan proses layanan bimbingan dan konseling sehingga mampu mengakselerasi pertumbuhan moral peserta didik. Penelitian ini menggunakan pendekatan research and development. Hasil pengujian lapangan menunjukkan bahwa program bimbingan dan konseling berbasis nilainilai budaya efektif untuk meningkatkan kemampuan penyesuaian diri peserta didik, baik dari segi aspek maupun pada tiap indikatornya. Program ini dapat diimplementasikan di sekolah-sekolah dalam upaya untuk meningkatkan kemampuan penyesuaian diri peserta didik.
\end{abstract}

Kata Kunci: bimbingan dan konseling, nilai-nilai budaya, dan penyesuaian diri

\begin{abstract}
Guidance and counseling culture values based program in this study is based on the consideration that sociocultural changes so quickly and massively, thus make it difficult for the students to adjustment. The Inability to adjustment well to the requirement of social environment (family, school, and community) as well as personal needs, causing the students to behave immorally which is a contradiction and against the norm (value), thus the students need a guidance and counseling assistance to the values as a guideline in adjusting. In providing a guidance and counseling services which based on Indonesian culture, a theoretical and empirical concept which is capable of integrating the values is required for the whole process and material of guidance and counseling services in order to accelerate the moral growth of the students. This study uses the research and development approach. The field test results indicate that the guidance and counseling culture values based program is effective to improve the adjustment ability of the students, both in terms of aspects and on each indicator. This program can be implemented in schools in an effort to improve the adjustment ability of learners.
\end{abstract}

Keywords: guidance and counselling, culture values, and adjustment

\section{PENDAHULUAN}

Kehidupan sosial budaya suatu masyarakat merupakan sistem terbuka yang selalu berinteraksi dengan sistem lain. Keterbukaan ini mendorong terjadinya pertumbuhan, pergeseran, dan perubahan nilai dalam masyarakat yang akan mewarnai cara berfikir dan perilaku individu. Corsini (Suherman, 2012: 9) mengatakan bahwa perubahanperubahan sosial yang begitu cepat (rapid social changes), sebagai konskuensi dari moderenisasi, industrialisasi, kemajuan ilmu pengetahuan dan teknologi telah mempengaruhi nilai-nilai moral etika dan gaya hidup (value system and way of life). Tidak semua individu mampu menyesuaikan diri dengan perubahan-perubahan sosial tersebut, kadang-kadang dapat membuat individu jatuh sakit atau mengalami gangguan penyesuaian diri (adjustment disorder). Oleh karena itu tugas konselor sebagai seorang psychoeducator menurut Kartadinata (2011: 91) harus kompeten dalam hal memahami 
kompleksitas interaksi individu dengan lingkungan dalam ragam konteks sosialbudaya; intervensi intrapersonal dan interpersonal dan lintas budaya".

Kebudayaan tidak semata-mata sebuah hasil, melainkan juga sebuah proses. Kartadinata (2010: 19) mengatakan "kebudayaan merupakan suatu proses dan sebagai hasil, dan pendidikan nasional adalah proses pembudayaan manusia Indonesia di dalam seting budaya nasional, sebagai kebudayaan puncak dari kebudayaan-kebudayaan daerah atau lokal." Penguatan budaya adalah kekuatan lokal yang harus diangkat dan menjadi program unggulan pendidikan yang dapat memperkokoh jati diri bangsa dalam memasuki proses internasionalisasi pendidikan.

Nilaimenjadihalpentingdalamperkembangan peserta didik karena nilai menjadi dasar pertimbangan moral bagi peserta didik dalam proses memilih dan mengambil keputusan. Suryadi (2011: 121) mengatakan "integrasi nilai dari seluruh bahan dan proses ajar dapat mengakselerasi pertumbuhan moral dan karakter peserta didik." Natawidjaja (2007: 16) mengatakan bahwa "dari manapun asal mula konsep dan praktik bimbingan dan konseling itu, landasan budaya nasional Indonesia seyogyanya dijadikan saringan, pedoman dan arahan bagi adaptasi konsep yang datang dari luar itu untuk melengkapi konsep dasar yang telah ada dan berkembang di Indonesia.

Tentunya upaya tersebut harus dilaksanakan secara proaktif sesuai tahap perkembangan remaja, dengan mengembangkan potensi yang dimiliki remaja dan memfasilitasi mereka secara sistemik dan terprogram untuk mencapai perkembangan yang optimal. Ahmadi (Rakhmat, 2011: 176) mengatakan bahwa:

Konseling berbasis budaya merupakan layanan konseling untuk konseli agar terjadi perkembangan berdasarkan kualitas individu manusia sebagai pelaku dan pembentuk budaya. Secara sederhana dapat dikatakan konseling berbasis budaya merupakan bentuk perlakuan konselor terhadap konseli melalui budayanya. Pendekatan tersebut mencoba mendekatkan konseli terhadap culture value system (sistem nilai budaya) agar mampu memahami diri, menerima diri, mengarahkan diri, dan mewujudkan diri dalam mencapai identitas kehidupannya yang bermakna.

Berdasarkan uraian masalah di atas, masalah utama yang diteliti dalam penelitian ini adalah bagaimana mengembangkan program bimbingan dan konseling berbasis nilai-nilai budaya yang efektif untuk meningkatkan kemampuan penyesuaian diri peserta didik?

Supaya lebih fokus, maka dijabarkan dalam pertanyaan penelitian sebagai berikut: (1) Bagaimana profil penyesuaian diri peserta didik SMAN di Kota Palangka Raya Tahun Ajaran 2012/2013?; (2) Bagaimana rumusan hipotetik program bimbingan dan konseling berbasis nilai-nilai budaya menurut para pakar dan praktisi?; dan (3) Bagaimana gambaran keefektifan program bimbingan dan konseling berbasis nilai-nilai budaya dalam meningkatkan kemampuan penyesuaian diri peserta didik?

Tujuan penelitian ini adalah menghasilkan program bimbingan dan konseling berbasis nilai-nilai budaya untuk meningkatkan kemampuan penyesuaian diri peserta didik. Secara khusus tujuan penelitian ini yaitu: (1) mendeskripsikan profil penyesuaian diri peserta didik, (2) merumuskan program bimbingan dan konseling berbasis nilai-nilai budaya, dan (3) menggambarkan kefektifan bimbingan dan konseling berbasis nilai-nilai budaya untuk meningkatkan kemampuan penyesuaian diri peserta didik.

Schneiders(1964:429)mengungkapkansetiap individu memiliki pola penyesuaian yang khas terhadap setiap situasi dan kondisi serta lingkungan yang dihadapinya. Bagaimana 
individu menyesuaikan diri di lingkungan rumah dan keluarganya, di sekolahnya, bagaimana individu dapat menyesuaikan diri dengan dirinya sendiri, serta cara menyesuaikan diri dengan lingkungan sosial menentukan adanya variasi penyesuaian diri (varietas of adjustment). Artinya adanya klasifikasi penyesuaian diri yang berdasarkan pada masalah dan situasi yang dihadapi dan berkaitan dengan tuntutan lingkungan. Empat variasi penyesuaian diri yang lebih penting dan krusial dalam kehidupan seorang manusia yaitu; penyesuaian dengan dirinya sendiri (personal adjustment), penyesuaian sosial (social adjustment), penyesuaian diri dengan pernikahan (marital adjustment), dan penyesuaian diri dengan pekerjaan (vocational adjustment).

Yusuf (2011: 198-199) mengatakan penyesuaian sosial dapat diartikan sebagai "kemampuan untuk mereaksi secara tepat terhadap realitas sosial, situasi, dan relasi. Remaja dituntut untuk memiliki kemampuan penyesuaian sosial itu, baik dalam lingkungan keluarga, sekolah, dan masyarakat. Diligkungan keluarga:

Menjalin hubungan yang baik dengan para anggota keluarga (orang tua dan saudara), (2) Menerima otoritas orang tua (mau menaati peraturan yang ditetapkan orang tua), (3) Menerima tanggung jawab dan batasanbatasan (norma) keluarga, dan (4) Berusaha untuk membantu anggota keluarga, sebagai individu maupun kelompok dalam mencapai tujuannya. Schneiders (Yusuf, 2011: 43) mengemukakan bahwa keluarga ideal ditandai oleh ciri-ciri: (a) minimnya perselisihan antar orang tua dan orang tua dengan anak, (b) ada kesempatan untuk menyatakan keinginan, (c) penuh kasih sayang, (d) penerapan disiplin yang tidak keras, (e) ada kesempatan untuk bersikap mandiri dalam berfikir, merasa dan berperilaku, (f) saling menghormati, menghargai (mutual respect) di antara orang tua dan anak, (i) orang tua memiliki emosi yang stabil, (j) berkecukupan dalam bidang ekonomi, dan (k) mengamalkan nilai-nilai moral dan agama. Di lingkungan sekolah: (1) Bersikap respek dan mau menerima peraturan sekolah, (2) Berpartisipasi dalam kegiatankegiatan sekolah, (3) Menjalin persahabatan dengan teman-teman di sekolah, (4) Bersikap hormat terhadap guru, pemimpin sekolah, dan staf lainnya. (5) Membantu sekolah dalam merealisasikan tujuan-tujuannya. Dilingkungan masyarakat: (1) Mengakui dan respek terhadap hak-hak orang lain, (2) Memelihara jalinan persahabatan dengang orang lain, (3) Bersikap simpati dan alturis terhadap kesejahteraan orang lain, dan (4) Bersikap respek terhadap nilai-nilai, hukum, tradisi, dan kebijakan-kebijakan masyarakat.

\section{Nilai-nilai Budaya}

Ranjabar (2006: 110) yang menyatakan bahwa beberapa nilai budaya yang cenderung mempengaruhi tingkat sosial budaya bangsa Indonesia, disebabkan hal-hal sebagai berikut: (1) Budaya santai sebagai akibat pengaruh alam dan lingkungan tidak mendorong terwujudnya etos kerja yang menghargai waktu, ketelitian, ketekunan, kesabaran dlam usaha, dan ketabahan dalam mengalami kesulitan, (2) Daya serap dan persepsi warga masyarakat terhadap budaya asing yang tingkat kemajuanya menunjukan dorongan bagi masyarakat, (3) Kecenderungan tetap mempertahankan nilai budya feodal, yaitu mentalitas priyayi dan orientasi kepada status yang mementingkan gelar dari pada kualitas manusia dan yang menghambat daya kreativitas serta kemampuan pribadi yang amat diperlukan dalam bidang ilmu pengetahuan dan teknologi, dan (4) Nilai budaya yang meninggikan orang lain atas dasar senioritas belaka atau pangkat. Sikap ini bertentangan dengan nilai keterbukaan dan kebenaran yang obyektif.

Balitbang Pusat Kurikulum, Kemendiknas, tahun 2010 mengeluarkan acuan nilai-nilai yang harus dikembangkan dalam pendidikan karakter dan budaya bangsa, seperti pada tabel 1. 
Tabel. 1

Nilai dan Deskripsi Nilai Pendidikan Budaya dan Karakter Bangsa

\begin{tabular}{|c|c|}
\hline Nilai & Deskripsi \\
\hline 1. Religius & $\begin{array}{l}\text { Sikap dan perilaku yang patuh dalam melaksanakan ajaran agama yang dianutnya, } \\
\text { toleran terhadap pelaksanaan ibadah agama lain, dan hidup rukun dengan pemeluk } \\
\text { agama lain. }\end{array}$ \\
\hline 2. Jujur & $\begin{array}{l}\text { Perilaku yang didasarkan pada upaya menjadikan dirinya sebagai orang yang selalu } \\
\text { dapat dipercaya dalam perkataan, tindakan, dan pekerjaan. }\end{array}$ \\
\hline 3. Toleransi & $\begin{array}{l}\text { Sikap dan tindakan yang menghargai perbedaan agama, suku, etnis, pendapat, sikap, } \\
\text { dan tindakan orang lain yang berbeda dari dirinya. }\end{array}$ \\
\hline 4. Disiplin & $\begin{array}{l}\text { Tindakan yang menunjukkan perilaku tertib dan patuh pada berbagai ketentuan dan } \\
\text { peraturan. }\end{array}$ \\
\hline 5. Kerja Keras & $\begin{array}{l}\text { Perilaku yang menunjukkan upaya sungguh-sungguh dalam mengatasi berbagai } \\
\text { hambatan belajar dan tugas, serta menyelesaikan tugas dengan sebaikbaiknya. }\end{array}$ \\
\hline 6. Kreatif & $\begin{array}{l}\text { Berpikir dan melakukan sesuatu untuk menghasilkan cara atau hasil baru dari sesuatu } \\
\text { yang telah dimiliki. }\end{array}$ \\
\hline 7. Mandiri & $\begin{array}{l}\text { Sikap dan perilaku yang tidak mudah tergantung pada orang lain dalam menyelesaikan } \\
\text { tugas-tugas. }\end{array}$ \\
\hline 8. Demokratis & $\begin{array}{l}\text { Cara berfikir, bersikap, dan bertindak yang menilai sama hak dan kewajiban dirinya } \\
\text { dan orang lain. }\end{array}$ \\
\hline 9. Rasa Ingin Tahu & $\begin{array}{l}\text { Sikap dan tindakan yang selalu berupaya untuk mengetahui lebih mendalam dan } \\
\text { meluas dari sesuatu yang dipelajarinya, dilihat, dan didengar. }\end{array}$ \\
\hline $\begin{array}{l}\text { 10. Semangat } \\
\text { Kebangsaan }\end{array}$ & $\begin{array}{l}\text { Cara berpikir, bertindak, dan berwawasan yang menempatkan kepentingan bangsa } \\
\text { dan negara di atas kepentingan diri dan kelompoknya. }\end{array}$ \\
\hline 11. Cinta Tanah Air & $\begin{array}{l}\text { Cara berfikir, bersikap, dan berbuat yang menunjukkan kesetiaan, kepedulian, dan } \\
\text { penghargaan yang tinggi terhadap bahasa, lingkungan fisik, sosial, budaya, ekonomi, } \\
\text { dan politik bangsa. }\end{array}$ \\
\hline $\begin{array}{l}\text { 12. Menghargai } \\
\text { Prestasi }\end{array}$ & $\begin{array}{l}\text { Sikap dan tindakan yang mendorong dirinya untuk menghasilkan sesuatu yang } \\
\text { berguna bagi masyarakat, dan mengakui, serta menghormati keberhasilan orang lain. }\end{array}$ \\
\hline $\begin{array}{l}\text { 13. Bersahabat/ } \\
\text { Komuniktif }\end{array}$ & $\begin{array}{l}\text { Tindakan yang memperlihatkan rasa senang berbicara, bergaul, dan bekerja sama } \\
\text { dengan orang lain. }\end{array}$ \\
\hline 14. Cinta Damai & $\begin{array}{l}\text { Sikap, perkataan, dan tindakan yang menyebabkan orang lain merasa senang dan } \\
\text { aman atas kehadiran dirinya. }\end{array}$ \\
\hline 15. Gemar Membaca & $\begin{array}{l}\text { Kebiasaan menyediakan waktu untuk membaca berbagai bacaan yang memberikan } \\
\text { kebajikan bagi dirinya. }\end{array}$ \\
\hline $\begin{array}{l}\text { 16. Peduli } \\
\text { Lingkungan }\end{array}$ & $\begin{array}{l}\text { Sikap dan tindakan yang selalu berupaya mencegah kerusakan pada lingkungan alam } \\
\text { di sekitarnya, dan mengembangkan upaya-upaya untuk memperbaiki kerusakan } \\
\text { alam yang sudah terjadi. }\end{array}$ \\
\hline 17. Peduli Sosial & $\begin{array}{l}\text { Sikap dan tindakan yang selalu ingin memberi bantuan pada orang lain dan } \\
\text { masyarakat yang membutuhkan. }\end{array}$ \\
\hline 18. Tanggung-jawab & $\begin{array}{l}\text { Sikap dan perilaku seseorang untuk melaksanakan tugas dan kewajibannya, yang } \\
\text { seharusnya dia lakukan, terhadap diri sendiri, masyarakat, lingkungan (alam, sosial } \\
\text { dan budaya), negara dan Tuhan Yang Maha Esa. }\end{array}$ \\
\hline
\end{tabular}

\section{Kerangka Teoretik Program Bimbingan dan Konseling Berbasis Nilai-nilai Budaya}

McDavid \& Hawthorn (2006: 15) mendefinisikan program sebagai hubungan bermakna yang dirancang dan diterapkan dengan tujuan. Suatu program dapat dipahami sebagai aktivitas dari kelompok yang dimaksudkan untuk mencapai satu atau beberapa sasaran hasil. Dalam konteks bimbingan dan konseling, program yang baik memiliki ciri-ciri sebagai berikut: (1) program disusun dan dikembangkan berdasarkan kebutuhan peserta didik, (2) diatur menurut prioritas dan kemampuan petugas, (3) program memiliki tujuan ideal, realistis dalam pelaksanaan, (4) lengkap dan menyeluruh, (5) sistematis, (6) terbuka dan luwes, (7) memungkinkan kerjasama dengan semua pihak, dan (8) adanya tindak lanjut untuk penyempurnaan program. (http:// kajianpsikologi.guru-indonesia.net/artikel_ 
detail-35459.html\#.UegpaW3vtF4).

Menurut Nurihsan, (2011: 18) program bimbingan dan konseling yang dikembangkan melalui perencanaan, pelaksanaan, penilaian, dan pengembangan yang dilakukan secara sistematis, akan menjamin tercapainya tujuan program bimbingan dan konseling. Hal itu sejalan dengan pendapat Yusuf (Supriatna, 2011: 61) yang mengatakan bahwa "dasar pertimbangan atau pemikiran tentang penerapan program bimbingan dan koseling adalah menyangkut upaya memfasilitasi peserta didik agar mampu mengembangkan potensi dirinya atau mencapai tugas-tugas perkembangannya."

Kehidupan individu (peserta didik) memiliki dimensi (budaya) yang sangat kompleks dan beraneka ragam. Keanekaragaman budaya tersebut seyogyanya menjadi dasar konselor untuk membuat sebuah konseptualisasi tentang hakikat individu/konseli dan sebagai pertimbangan dalam memahami serta memperlakukan mereka. Pedersen (McLeod, 2010: 274) mengatakan bahwa keanggotaan dari kultur atau beberapa kultur merupakan salah satu pengaruh paling penting terhadap perkembangan identitas seseorang, dan karena itu masalah emosional dan perilaku yang dibawa oleh seseorang ke ruang konseling bisa jadi cerminan bagaimana hubungan, moral, dan pemahaman terhadap "hidup yang nyaman" dan didefinisikan dalam kultur (atau beberapa kultur) tempat di mana seseorang hidup.

Untuk memastikan bahwa program dalam penelitian ini telah sesuai dan memadai dengan kebutuhan peserta didik dan prioritas masyarakat sekolah, efisien, dan efektif dalam memfasilitasi individu, serta melalui perencanaan, penilaian, dan evaluasi yang memadai, maka dibutuhkan sebuah panduan baku untuk dijadikan acuan pengembangannya. Joyce, Weil, dan Calhoun (Supriatna, 2010: 55) mengatakan bahwa setiap model dalam kerangka memfasilitasi individu belajar atau berubah, baik dimensi pribadi, sosial, intelektual, maupun perilakunya, dapat dianalisis dari segi landasan teoreik atau asumsi model, tujuan, prinsip-prinsip reaksi, sistem sosial, sistem penunjang, dan tahapan langkahlangkah (syntax). Selanjutnya dalam Nova Scotia, Department of Education (2010) menjelaskan bahwa dalam mendesain dan mengimplementasikan program bimbingan dan konseling yang efektif dapat melalui langkah-langkah beriku: initiate the program, establish an advisory comitte, assess needs, determine resources, identifyexpected student outcome, define program activities, implement program activities, dan evaluate program.

Merujuk pada beberapa uraian tentang tahapan-tahapankelayakandalampenyusunan program dan didasari atas pertimbangan kebutuhan penelitian serta paradigma pemikiran peneliti, maka kerangka teoretik program bimbingan dan konseling berbasis nilai-nilai budaya untuk meningkatkan kemampuan penyesuaian diri peserta didik meliputi: rasional, asumsi program, visi dan misi program, deskripsi kebutuhan, tujuan program, kompetensi konselor, strategi layanan, rencana operasional (action plan), pengembangan satuan pelayanan, evaluasi dan indikator keberhasilan.

\section{METODE PENELITIAN}

Sugiyono (2008: 80) mengatakan "populasi adalah wilayah generalisasi yang terdiri atas objek/subjek yang mempunyai kualitas dan karakteristik tertentu yang ditetapkan oleh peneliti untuk dipelajari dan kemudian ditarik kesimpulan." Populasi dalam penelitian ini adalah peserta didik SMAN se Kota Palangka Raya, yang terbagi dalam lima kecamatan, yaitu Kecamatan Pahandut, Kecamatan Jekan Raya, Kecamatan Bukit Batu, Kecamatan Rakumpit, dan Kecamatan Sabangau. Sedangan untuk Sekolah Menengah Atas Negeri nya terdiri dari: SMAN 1, SMAN 
2, SMAN 3, SMAN 4, SMAN 5, SMAN 6, SMAN 7, dan SMAN 8 yang berjumlah 1502 orang. Untuk lebih rincinya dapat dilihat pada tabel 2 .

Penentuan sampel penelitian menggunakan teknik multistage cluster sampling, yang merupakan bagian dari probability sampling. Sugiyono (2008: 82) mengatakan bahwa "probability sampling adalah teknik pengambilan sampel yang memberikan peluang sama bagi setiap unsure (anggota) populasi untuk dipilih menjadi anggota." Teknik sampling menggunakan tiga tahap, yaitu tahap pertama menentukan sampel daerah (dipusat kota dan pinggiran kota), tahap kedua menentukan secara random sekolah pada tiap daerah (diambil 2 sekolah tiap daerah), selanjutnya pengambilan sampel berdasarkan kelas (diambil dua kelas pada setiap jurusan) sehingga mendapatkan jumlah total sampel 429 orang. Kemudian dilakukan penelitian pendahuluan pada sampel tersebut, dan didapatkan sampel yang memiliki penyesuaian diri rendah sebanyak 82 orang, yang kemudian dijadikan sebagai sampel untuk uji coba efektivitas program.

Metode penelitian pada dasarnya merupakan cara ilmiah untuk mendapatkan data dengan tujuan dan kegunaan tertentu (Sugiyono, 2008: 2). Sesuai dengan permasalahan yang diteliti dan tujuan penelitian, maka penelitian ini menggunakan pendekatan penelitian dan pengembangan (research and development). Menurut Sugiyono (2008: 297) mengatakan bahwa penelitian pengembangan adalah metode penelitian yang digunakan untuk menghasilkan produk tertentu, dan menguji keefektifan produk tersebut.

Sesuai dengan tujuan yang akan dicapai, penelitian ini dilaksanakan dalam sembilan tahap kegiatan, yaitu: tahap satu persiapan, tahap dua merancang program hipotetik, tahap tiga uji kelayakan program hipotetik, tahap empat perbaikan program hipotetik, tahap lima uji coba terbatas, tahap enam revisi hasil uji coba terbatas, tahap tujuh uji lapangan program, tahap delapan merancang program akhir, dan tahap sembilan diseminasi program.

\section{HASIL PENELITIAN}

Profil Penyesuaian Diri Peserta Didik Secara Umum, penelitian pendahuluan bertujuan untuk mendapatkan data empirik tentang profil penyesuaian diri peserta didik ( $\mathrm{n}=$ 429) di SMA Negeri Kota Palangka Raya tahun pelajaran 2012/2013. Hasil penelitian pendahuluan ini menjadi bahan pertimbangan dalam mengembangkan program bimbingan dan konseling berbasis nilai budaya. Profil penyesuaian diri peserta didik disajikan di halaman-halaman berikut.

Hasil penelitian pendahuluan menemukan bahwa profil penyesuaian diri peserta didik secara umum menunjukkan adanya variasi dengan urutan berada pada kategori tinggi $45 \%$, sedang $36 \%$, dan rendah $19 \%$ dengan skor rata-rata sebesar 200, skor minimal 114, skor maksimal 316, dan standar deviasi sebesar 66,66. Secara lebih rinci profil penyesuaian diri peserta didik berdasarkan hasil penelitian pendahuluan disajikan pada tabel.

Tabel 2

Profil Penyesuaian Diri Peserta Didik Secara Umum

\begin{tabular}{ccccc}
\hline Pedoman & Skor & Frekuensi & Persentase & Kategori \\
\hline $\mathrm{X}>(\mathrm{Me}+1 \mathrm{~s})$ & $\mathrm{X}>266,66$ & 156 & $36 \%$ & Tinggi \\
\hline $\begin{array}{c}(\mathrm{Me}-1 \mathrm{~s})<\mathrm{X}< \\
(\mathrm{Me}+1 \mathrm{~s})\end{array}$ & $\begin{array}{c}133,34<\mathrm{X}< \\
266,66\end{array}$ & 191 & $45 \%$ & Sedang \\
\hline $\mathrm{X}<(\mathrm{Me}-1 \mathrm{~s})$ & $\mathrm{X}<133,34$ & 82 & $19 \%$ & Rendah \\
\hline Total & & 429 & $100 \%$ & \\
\hline
\end{tabular}

Adapun bila dipaparkan dalam bentuk grafik maka profil penyesuaian diri peserta didik secara umum akan tampak seperti pada grafik1 di bawah ini. 


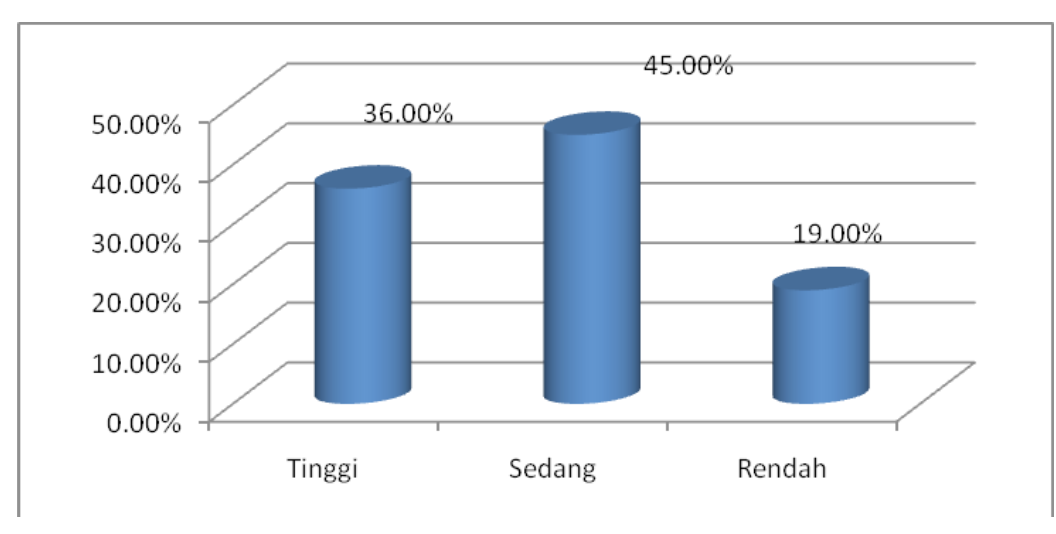

Grafik 1

Profil Penyesuaian Diri Peserta Didik Secara Umum

\section{Pembahasan Hasil Penelitian Pendahuluan}

Studi pendahuluan penelitian ini menunjukkan hasil bahwa kemampuan penyesuian diri peserta didik kelas XI SMAN Kota Palangka Raya secara umum dapat dikatakan dalam kategori sedang. Temuan ini dapat dimaknai bahwa secara umum peserta didik kelas XI SMAN Kota Palangka Raya belum sepenuhnya memiliki kemampuan penyesuaian diri yang baik atau peserta didik telah memiliki kemampuan penyesuaian diri akan tetapi belum dipergunakan secara optimal.

Peserta didik sekolah menengah atas termasuk dalam periode remaja. Hurlock, (1980: 206) mengatakan awal masa remaja berlangsung kira-kira dari tiga belas tahun sampai enam belas atau tujuh belas tahun, dan akhir masa remaja bermula dari usia enam belas atau tujuh belas tahun sampai delapan belas tahun. Perubahan dalam sikap dan perilaku selama masa remaja sejajar dengan tingkat perubahan fisik. Selama awal masa remaja, ketika perubahan fisik terjadi dengan cepat, perubahan perilaku dan sikap juga berlangsung pesat. Kalau perubahan fisik menurun maka perubahan sikap dan perilaku juga menurun. Perkembangan fisik yang cepat dan penting disertai dengan cepatnya perkembangan mental yang cepat, semua perkembangan itu menimbulkan perlunya penyesuaian mental dan perlunya membentuk sikap, nilai dan minat baru
(Hurlock, 1980: 207).

Penyesuaian diri merupakan salah satu persyaratanpentingbagiterciptanyakesehatan jiwa/mental individu. Banyak individu yang menderita dan tidak mampu mencapai kebahagiaan dalam hidupnya, karena ketidakmampuannya dalam menyesuaikan diri, baik dengan kehidupan keluarga, sekolah, pekerjaan dan dalam masyarakat pada umumnya. Tidak jarang pula ditemui bahwa orang-orang mengalami stres dan depresi disebabkan oleh kegagalan mereka untuk melakukan penyesuaian diri dengan kondisi yang penuh tekanan. Schneiders (1964: 55) mengatakan bahwa salah satu tujuan dari istilah "mental healt" adalah memberikan penekanan pada salah satu aspek yang paling penting dari penyesuaian diri manusia. Tentu saja, kesehatan mental adalah kondisi yang diperlukan untuk penyesuaian diri yang baik, dan dengan aturan yang sama, ketika seseorang sehat secara mental lebih sedikit kemungkinan untuk maladjustment atau dapat dikatakan that mental health is the key to wholesome adjustment.

Anna Freud (Hurlock, 1980: 208) mengatakan bahwa banyak kegagalan, yang seringkali disertai akibat yang tragis, bukan karena ketidakmampuan individu tetapi karena kenyataan bahwa tuntutan yang diajukan kepadanya justru pada saat semua tenaganya telah dihabiskan untuk mencoba mengatasi masalah pokok yang disebabkan oleh pertumbuhan dan perkembangan seksual 
yang normal. Penyesuaian diri memang erat kaitannya dengan perkembangan individu.

Schneiders (1964: 122) mengatakan bahwa faktor-faktor penentu penyesuaian diri identik dengan faktor-faktor yang meregulasi perkembangan dan kemunculnya secara bertahap dengan kepribadian. Faktor penentu dapat dikelompokkan dengan cara sebagai berikut: (1) Kondisi fisik dan determinan, termasuk keturunan, konstitusi fisik, sistem saraf, kelenjar, dan otot, kesehatan, penyakit, dan sebagainya; (2) Perkembangan dan pematangan, terutama intelektual, sosial, moral, dan pematangan emosional; (3) Penentuan psikologis, termasuk pengalaman, belajar, pengkondisian, menentukan nasib sendiri, frustrasi, dan konflik; (4) Kondisi lingkungan, khususnya rumah, keluarga, dan sekolah; dan (5) Determinan budaya, termasuk agama.

Menjadikan remaja mampu berperan serta dan melaksanakan tugasnya, baik sebagai individu maupun sebagai anggota masyarakat tidaklah mudah, karena masa remaja merupakan masa peralihan dari masa kanak-kanak ke masa dewasa. Pada masa ini dalam diri remaja terjadi pertumbuhan dan perkembangan yang pesat pada fisik, psikis, maupun sosial. Salah satu tugas perkembangan masa remaja yang tersulit adalah yang berhubungan dengan penyesuaian diri sendiri dan lingkungan sosial. Remaja harus menyesuaikan diri dengan lawan jenis dalam berhubungan yang belum pernah ada, lingkungan sekolah dan harus menyesuaikan dengan orang dewasa baik di dalam maupun di luar lingkungan keluarga. Untuk mencapai tujuan dari pola sosialisasi dewasa, remaja harus memiliki kemampuan penyesuaian diri yang baik (good adjustment). Agar penyesuaian diri yang dilakukan terhadap lingkungan sosial berhasil, maka remaja harus menyelaraskan antara tuntutan yang berasal dari dalam dirinya dengan tuntutan-tuntutan yang diharapkan oleh lingkungannya, sehingga remaja mendapatkan kepuasan dan memiliki kepribadian yang sehat.
Ditinjau dari aspek penyesuaian diri yang baik (good adjustmen), hasil penelitian pendahuluan menunjukkan bahwa aspek penyesuaian pribadi, penyesuaian keluarga, penyesuaian sekolah, dan penyesuaian masyarakat berada pada kategori sedang. Berdasarkan indikator setiap aspek penyesuaian diri dapat dikemukakan bahwa peserta didik yang memenuhi kategori tinggi, yaitu pada aspek: (1) penyesuaian pribadi, meliputi indikator menerima dan memanfaatkan perubahan fisik secara efektif sebesar (16\%), mampu memerankan peran seks (maskulin dan feminim) sebesar (51\%), mampu mengendalikan perubahan emosi dengan baik dan efektif sebesar (2\%), mempersiapkan kemandirian secara emosi dan ekonomi dari orang tua sebesar (55\%), serta bertanggung jawab dan berfikir realistis sebesar (6\%). (2) penyesuaian sekolah, meliputi indikator menjalin hubungan yang baik dengan para anggota keluarga sebesar $(33 \%)$, menerima otoritas orang tua (menaati peraturan yang ditetapkan) sebesar (43\%), menerima tanggung jawab dan batasanbatasan (norma) keluarga sebesar (53\%), dan berusaha untuk membantu anggota keluarga dalam mencapai tujuannya sebesar $(60 \%)$. (3) penyesuaian sekolah, meliputi indikator bersikap respek dan mau menerima peraturan sekolah sebesar (4\%), berpartisipasi dalam kegiatan-kegiatan sekolah sebesar (67\%), menjalin persahabatan dengan teman-teman di sekolah sebesar (12\%), bersikap hormat terhadap guru, pemimpin sekolah, dan staf lainnya sebesar (21\%), dan membantu sekolah dalam merealisasikan tujuantujuannya sebesar (60\%). (4) penyesuaian masyarakat, meliputi indikator mengakui dan respek terhadap hak-hak orang lain sebesar (61\%), indikator memelihara jalinan persahabatan dengan orang lain sebesar (61\%), bersikap simpati dan alturis terhadap kesejahteraan orang lain sebesar (47\%), dan respek terhadap nilai-nilai, hukum, tradisi, dan kebijakan masyarakat sebesar (5\%). 
Fakta empirik tersebut menunjukkan bahwa pada setiap aspek terdapat indikator yang belum dikuasai secara optimal sebagai kemampuan penyesuaian diri peserta didik. Dengan kata lain, belum semua peserta didik memiliki kemampuan menyesuaikan diri yang baik (good adjustment) dengan diri sendiri, keluarga, sekolah dan masyarakat. Padahal, pada umumnya mereka akan memasuki mada dewasa awal yaitu pada usia delapan belas tahun, bahkan secara hukum di Indonesia pada saat individu berusia tujuh belas tahun maka ia dikatakan dewasa. Hurlock (1980: 209) mengatakan bahwa "tugas perkembangan pada masa remaja dipusatkan pada penanggulangan sikap dan pola perilaku yang kekanak-kanakan dan mengadakan persiapan untuk menghadapi penyesuaian pada masa dewasa." Penyesuaian diri yang baik pada tahun-tahun kehidupan berikutnya sangat bergantung pada seberapa jauh seseorang dapat menyesuaikan diri, baik terhadap perubahan fisik maupun psikologis (Hurlock, 1980: 2). Dapat diartikan bahwa, berbagai indikator penyesuaian diri yang belum optimal tersebut sangat penting untuk dikembangkan hingga menjadi good adjustment.

Di samping itu, fakta tersebut juga mengindikasikan bahwa peserta didik sudah mampu menyesuaikan diri. Namun, kemampuan penyesuaian diri tersebut belum optimal sehingga mengarah kepada perlunya upaya pengembangan dalam bentuk program yang dibingkai dalam kegiatan bimbingan dan konseling.

Kesulitan menyesuaikan diri baik secara fisik maupun psikologis pada peserta didik memerlukan penangan yang intensif dan terampil. Menurut Schneiders (1964: 535536) ada empat metode dasar treatment yang dapat dilakukan oleh konselor, yaitu: (1) remedial, ketika kesulitan itu melibatkan beberapa kekurangan yang bisa diatasi dengan instruksi atau pelatihan, (2) informational or advisory, ketika masalah terutama perangkat periferal (gejala-gejala kejasmanian) dan tidak melibatkan gangguan psikologis yang mendalam atau kerusakan organik, (3) psychotherapeutic, ketika ada personality maladjustment serius atau gangguan mental yang psikogenik dari asal, dan (4) medical, ketika memerlukan penggunaan obat atau manipulasi faktor fisik dan agents (zat).

Dari keempat metode yang dianjurkan oleh Schneiders tersebut dan memperhatikan tingkat masalah penyesuaian diri yang dialami peserta didik serta konteks tugas layanan profesional bimbingan dan konseling, maka yang relevan untuk dijadikan metode treatment adalah remedial dan informational or advisory.

Selanjutnya Rogers (1942: 12-15) juga menjelaskan beberapa pendekatan treatmen yang dapat digunakan untuk mengatasi masalah penyesuaian diri, diantaranya yaitu:

Preventive Measures. Penekanan harus di tempatkan pada fakta bahwa kebijakan administratif tertentu dimaksudkan untuk pencegahan ketidakmampuan menyesuaikan diri. Kebijakan tentang penempatan kelas dan promosi di sekolah, mungkin, misalnya, sengaja direncanakan untuk mencegah banyaknya maladjusted.

Environmental Treatment. Metode membantu orang-orang yang menemukan dirinya dalam kesulitan masalah perilaku, gagal, terganggu secara emosional, neurotik, menunggak kelas, kurang bahagia dalam pernikahan. Pengobatan masalah ini dapat melalui manipulasi lingkungannya. Bentukbentuk pengobatan tersebut dapat banyak sekali macamnya. Mungkin termasuk setiap kemungkinan sarana lingkungan individu, fisik dan psikologis, yang dibuat lebih kondusif untuk penyesuaian diri. Jika hanya untuk satu orang, mungkin memberi penempatan di rumah istirahat, anak dapat di tempatkan dalam kelompok remedial membaca seminggu sekali. Jika perubahan tersebut dengan matang direncanakan dan 
dieksekusi dengan terampil, mereka bisa sangat efektif dalam mengubah sikap, perilaku, dan penyesuaian individu.

Direct Treatment. Pertama, individu maladjusted secara langsung dipengaruhi dalam upaya untuk membantu dia mendapatkan hubungan yang lebih memuaskan untuk situasinya. Dalam kategori ini termasuk treatmen wawancara, metode konseling dan psikoterapi. Kedua, direct treatment melahirkan beberapa hubungan dengan orang lain dan proses konseling, dapat digambarkan sebagai terapi ekspresif, karena katarsis perasaan dan sikap memainkan bagian yang sangat penting dalam masing-masing treatmen. Bagian ini akan mencakup terapi bermain, terapi kelompok, terapi seni, psychodramatics, dan teknik serupa lainnya. Kedua teknik tersebut memainkan peran membantu dalam treatmen masalah pribadi. Dalam setiap kasus elemen dasar dari pengobatan adalah ekspresi penuh perasaan baik melalui media nonverbal seperti tanah liat, boneka, gambar, dan sejenisnya, atau melalui cara verbal, di mana perasaan diproyeksikan ke orang lain, seperti spontaneous or guided dramatic productions.

Semua treatment tersebut dapat berjalan efektif apabila menurut Rogers (1942: 18) dalam konseling "consists of a definitely structured permissive relationship which allows the client to gain an understanding of himself to a degree which enables him to take positive steps in the light of his new orientation." Artinya, proses konseling harus dilakukan secara terstruktur dan memungkinkan klien mendapatkan pemahaman tentang dirinya sehingga ia dapat mengambil keputusan dengan pengalaman baru yang ia dapatkan dari konseling.

\section{Hasil Uji Efektivitas Program}

Hipotesis penelitian berbunyi: "Program Bimbingan dan Konseling Berbasis Nilai Budaya Efektif untuk Meningkatkan Kemampuan Penyesuaian Diri Peserta Didik". Hipotesis dalam penelitian ini dijabarkan ke dalam hipotesis statistic sebagai berikut:

$$
\begin{aligned}
& \mathrm{H}_{0}: \mu_{\text {eksperimen }}=\mu_{\text {kontrol }} \\
& \mathrm{H}_{1}: \mu_{\text {eksperimen }}>\mu_{\text {control }}
\end{aligned}
$$

Kriteria pengujiannya, tolak $\mathrm{H}_{0}$ jika harga signifikansi dari statistik (p) lebih kecil dari alpa $(\alpha)$. Dalam penelitian ini harga $\alpha$ ditetapkan sebesar 0,05.

\section{a. Uji Hipotesis Total Variabel Penyesuian Diri}

Untuk menguji hipotesis, data dianalisis dengan menggunakan teknik anacova. Prosedur perhitungannya menggunakan perangkat lunak komputer (software) SPSS 17 dengan bantuan menu general linear model dan sub menu uinivariat analisys of variance. Hasil perhitungan total skor variabel penyesuaian diri menghasilkan harga statistik sebagai berikut:

Hasil uji anacova sebagai mana tampak output Tests of Between-Subjects Effects menunjukkan harga $\mathrm{F}=258,500$ dan $\mathrm{p}=0,000$. Tampak bahwa harga $\mathrm{p}$ jauh lebih kecil dari 0,05 , yang berarti $\mathrm{H}_{0}$ ditolak dan $\mathrm{H}_{1}$

Tabel 3

Harga Statistik Deskriptif Variabel Penyesuaian Diri Peserta Didik

\begin{tabular}{ccccccc}
\hline Kelompok & Mean & $\begin{array}{c}\text { Std. } \\
\text { Deviation }\end{array}$ & N & F & B & p/Sig \\
\hline Eksperimen & 256.27 & 43.833 & 41 & 258,500 & 121.242 & 0,000 \\
\hline Kontrol & 134.95 & 19.307 & 41 & & $0^{\mathrm{a}}$ & \\
\hline Total & 195.61 & 69.698 & 82 & & & \\
\hline
\end{tabular}

diterima atau sama dengan $\mathrm{H}_{1}: \mu_{\text {eksperimen }}>\mu$ control. Dengan demikian terdapat perbedaan yang signifikan antara skor penyesuaian diri subjek pada kelompok eksperimen dengan kelompok kontrol. Dengan kata lain program bimbingan dan konseling berbasis 
nilai budaya efektif untuk meningkatkan kemampuan penyesuaian diri peserta didik. Kelompok eksperimen memiliki skor penyesuaian diri lebih tinggi dibandingkan dengan kelompok kontrol dengan selisih 121,32. Dilihat dari standart deviation nya nampak bahwa perolehan skor kelompok eksperimen (43.833) lebih beragam dibandingkan dengan kelompok kontrol (19.307).

Dengan melihat output parameter estimates diperoleh harga B sebesar 121,242 dan signifikansi sebesar 0,000. Artinya, apabila ada dua subjek (kelompok eksperimen dan kontrol) yang satu diberikan treatment dan yang satunya tidak mengikuti treatment maka kelompok yang diberikan treatment akan memiliki skor penyesuaian diri lebih tinggi sebesar 121,242 dibandingkan dengan subjek yang yang tidak mengikuti treatment. Jika digambarkan dengan grafik maka kan tampak sebagai berikut:

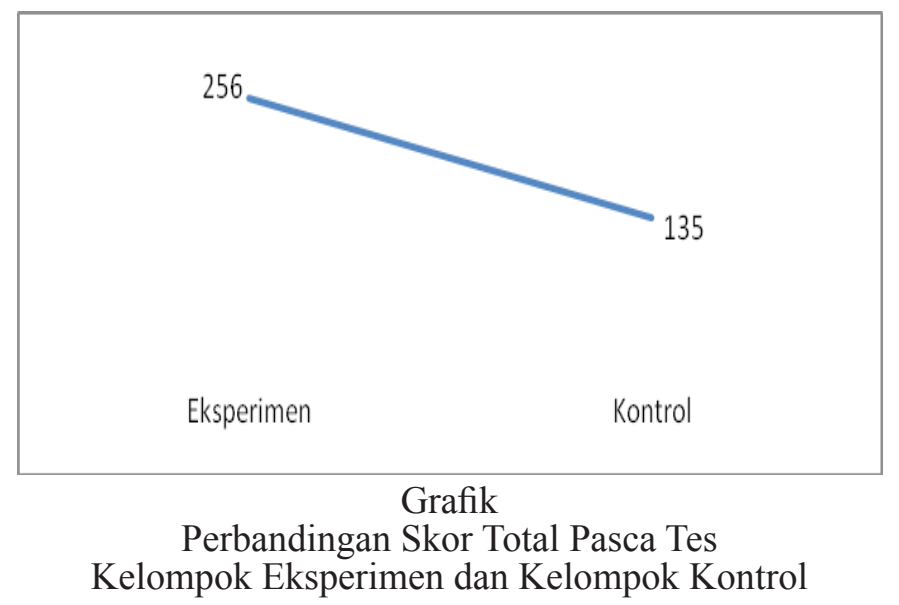

\section{KESIMPULAN}

Kesimpulan hasil penelitian pengembangan program bimbingan dan konseling berbasis nilai-nilai budaya untuk meningkatkan kemampuan penyesuaian diri peserta didik dipaparkan sebagai berikut: (1) Hasil studi pendahuluan menunjukkan bahwa secara umum penyesuaian diri peserta didik kelas XI SMAN Kota Palangka Raya berada pada kategori sedang. Demikian pula ditinjau dari aspek-aspek penyesuaian diri yang meliputi penyesuaian pribadi, penyesuaian keluarga, penyesuaian sekolah dan penyesuaian masyarakat juga menunjukkan kategori sedang ke arah. Dengan kata lain temuan ini dapat dimaknai bahwa secara umum peserta didik kelas XI SMAN Kota Palangka Raya telah memiliki kemampuan penyesuaian diri tetapi belum optimal, dan cenderung ke arah well adjustment; (2) Program bimbingan dan konseling berbasis nilai-nilai budaya untuk meningkatkan kemampuan penyesuaian diri peserta didik dikembangkan menggunakan pendekatan penelitian dan pengembangan (research and development). Tahapantahapan untuk mengembangkan program meliputi: persiapan pengembangan program, merancang program hipotetik, uji kelayakan program, revisi program hipotetik, uji coba terbatas, revisi hasil uji coba terbatas, pengujian lapangan, merancang program akhir, dan diseminasi program. Struktur program tersebut terdiri dari rasional, asumsi program, deskripsi kebutuhan, tujuan program, kompetensi konselor, metode layanan, rencana operasional (action plan), pengembangan satuan pelayanan, evaluasi dan indikator keberhasilan; dan (3) Hasil pengujian lapangan menunjukkan bahwa program bimbingan dan konseling berbasis nilai-nilai budaya efektif untuk meningkatkan kemampuan penyesuaian diri peserta didik kelas XI SMAN Kota Palangka Raya, baik dari segi aspek maupun pada tiap indikatornya. 


\section{DAFTAR PUSTAKA}

Department of Education Student Services. (2010). Comprehensive Guidance and Counselling. Nova Scotia.

Hurlock, E.B. (1980). Alih Bahasa. Istiwidayati \& Soedjarwo. Psikologi Perkembangan: Suatu Pendekatan Sepanjang Rentang Kehidupan, Edisi ke-5. Jakarta: Penerbit Erlangga.

Kartadinata, S. (2011). Kerangka Kerja Bimbingan dan Konseling dalam Pendidikan: Pendekatan Ekologis Sebagai Alternatif. Penyunting: Suherman dan Nandang Budiman. (Pendidikan dalam Perspektif Bimbingan dan Konseling). Bandung: UPI Press.

Kartadinata, S. (2010). Isu-isu Pendidikan: Antara Harapan dan Kenyataan. Bandung. UPI Press.

McDavid, J. \& Hawthorn, L. (2006). Program evaluation and performance measurement. Thousand Oaks, CA: Sage.

McLeod, J. (2010). Alih Bahasa oleh A. K. Anwar. Pengantar Konseling: Teori dan Studi Kasus. Jakarta: Kencana.

Natawidjaja, R. (2007). Konseling Kelompok: Konsep Dasar dan Pendekatan.Bandung: SPS UPI.

Nurihsan, J. (2011). Membangun Peradaban Bangsa Indonesia Melalui Pendidikan dan Bimbingan Komprehensif yang Bermutu. Bandung: Pidato Pengukuhan Guru Besar/Profesor dalam Bidang Bimbingan dan Konseling pada FKIP UPI.

Rakhmat, C. (2011). Hakikat Konseling Berbasis Budaya. Penyunting: Suherman dan Nandang Budiman. (Pendidikan dalam Perspektif Bimbingan dan Konseling). Bandung: UPI Press.

Ranjabar, J. (2006). Sistem Sosial Budaya Indonesia (Suatu Pengantar). Jakarta: Ghalia Indonesia.

Rogers R. C. (1942). Counseling and Psychotherapy: Newer Concept in Practice. New York: Houghton Mieelin Company.

Schneiders, A. A. (1964). Personal Adjustmen and Mental Health. Holt Rinehart and Wiston, New York, USA.

Sugiyono. (2008). Metode Penelitian Kuantitatif, Kualitatif, dan R\&D. Bandung: Alfabeta.

Suherman, U. (2012). Membangun Karakter dan Budaya Bangsa Melalui Bimbingan Komprehensif Berbasis Nilai-nilai Al Qur'an. Bandung: Pidato Pengukuhan Guru Besar/Profesor dalam Bidang Bimbingan dan Konseling pada FKIP UPI.

Suryadi, A. (2011). Pendidikan Karakter Bangsa: Pendekatan Jitu Menuju Sukses Pembangunan Pendidikan Nasional. Editor: Dasim Budimansyah dan Kokom Komalasari. (Pendidikan Karakter: Nilai Inti Bagi Upaya Pembinaan Kepribadian Bangsa). Bandung: Laboratorium PKN UPI.

Supriatna, M. (2011). Bimbingan dan Konseling Berbasis Kompetensi: Orientasi Dasar Pengembangan Profesi Konselor. Jakarta: Rahja Grafindo Persada.

Supriatna, M. (2010). Model Konseling Aktualisasi Diri untuk. Mengembangkan Kecakapan Pribadi Mahasiswa. Disertasi. Bandung: SPS UPI. Tidak Dipublikasikan.

Yusuf, LN. S. (2011). Psikologi Perkembangan Anak \& Remaja. Bandung: Remaja Rosdakarya. 